\title{
THE EXERCISE POWER OF CAPITOL IN PANEM AS AMBIGUOUS UTOPIA CITY (TRILOGY HUNGER GAMES)
}

\author{
Yudhi Pratama Suardi \\ UIN Alauddin Makassar \\ Yupraa16@gmail.com
}

\begin{abstract}
This research discussed about the Exercise Power of Capitol in Panem as Ambiguous Utopia City in Trilogy Hunger Games Movies such as Hunger Games, Catching Fire, Mockingjay Part I and Part II. The aims of this research were to describe the processes of Capitol created Panem as Ambiguous Utopia City and to find out the forms of Ambiguous Utopia City in Panem. This research used postcolonialism approach by Upstone's theory which describe about post space. This research applied descriptive qualitative method. This research used note taking as the instrument in order to get the valid data. The findings showed that the borders and orders were used by Capitol to create Panem as Ambiguous Utopia City and the findings also showed that there were three city forms in Panem such as Utopia, Nowhere, and Carnival City. The researcher concluded that Capitol as the central city which became the ambiguous Utopia City.
\end{abstract}

Keywords: Post-colonialism, Post Space, Capitol City, Border, Order

\section{Abstrak}

Penelitian ini membahas tentang Latihan Kekuatan Capitol di Panem sebagai Kota Utopia yang ambigu di Trilogy Hunger Games Movies seperti Hunger Games, Catching Fire, Mockingjay Bagian I dan Bagian II. Tujuan dari penelitian ini adalah untuk mendeskripsikan proses Capitol yang menciptakan Panem sebagai Kota Utopia yang ambigu dan untuk mengetahui bentuk Kota Utopia yang ambigu di Panem. Penelitian ini menggunakan pendekatan pasca kolonialisme dengan teori Upstone yang menggambarkan tentang ruang pos. Penelitian ini menggunakan metode deskriptif kualitatif. Penelitian ini menggunakan catatan sebagai instrumen untuk mendapatkan data yang valid. Temuan menunjukkan bahwa perbatasan dan perintah digunakan oleh Capitol untuk menciptakan Panem sebagai Kota Utopia yang ambigu dan temuan tersebut juga menunjukkan bahwa ada tiga bentuk kota di Panem seperti Utopia, Nowhere, dan Carnival City. Peneliti menyimpulkan bahwa Capitol sebagai pusat kota yang menjadi Kota Utopia yang ambigu.

Kata kunci: Pasca Kolonialisme, Ruang Pos, Kota Capitol, Perbatasan, Ketertiban

\section{INTRODUCTION}

Colonialism is a specific form of cultural exploitation which is developing in Europe for 400 years (Ashcroft, 2001:45). It is the establishment and control of an area, for an extended period of time, by a sovereign power over a subordinate and other people which are segregated and separated from the ruling power. Features of the colonial situation include political and legal domination over the 
other society, relations of economic and political dependence, institutionalized racial and cultural inequalities.

Upstone (2009:4) says that Colonizers claim the territory using the concept of space. They develop their policy based on religious evangelism or economic development in the city or country. The colonial achievement is often judged in terms of the subsequent productivity and political stability of the space. There are many negative impacts of colonizers in the city. Therefore, some researchers feel interesting to analyze this case and also they make a theory to analyze, explain, and respond the cultural legacy of colonialism and imperialism, called post colonialism. Upstone (2009:5) says that the place can be seen as manifestation of post colonialism. The area of colonialism contradictory condition usually involves in an alternative space that pinpoints to freedom, independency with no boundary and of independency itself. The colonizers use concept of space to create a city. Upstone (2009:11) says that through seizing the defined fluidity of abstract space and imbuing locations with a political function, post colonialism authors create space as a site of possibility and resistance.

City is the best space for the citizens to live in this world. Most people can agree that cities are places where large number of people live and work. Sennet (1969:23) says that cities are built closely to each other, often, today, walls to walls. The city as a site of invention had defined labor as modern and industrialized in a capitalist system in contrast to rural, traditional, and pre modern subsistence labor. All of the citizens want to live in beautiful city which called Utopia City. Utopia is the creation from human imagination that believe utopia as a solution of the imperfect world. Sunder (2013:2) says that utopian is a satirical reflection on the social and political problems of England in the sixteenth century, while, at the same time showing ambiguity in the proposed solutions. Therefore, Upstone (2009, 85-113) says that there are some forms of city such as Utopian City, Desire City, Nowhere City, Carnival City.

Recently, Ambiguous Utopia City is a big problem for the residents. This is proven in Palestine. Rabinowitz (2001:74) says that seen from the Arab world, the Palestinian residents of Israel emerge as an ambiguous and problematic element whose status in the national arena is yet to be determined, and whose very loyalty to the Palestinian nation might still be suspect. Israel's willingness, where it exists, to integrate its Palestinian citizens into economic, political and social life, might in fact further detract their chances of clarifying their credentials in the eyes of Palestinians generally. Trapped in this dual marginality and held between the two centers of political gravity, the Palestinian citizens of Israel are painfully aware of two connecting national narratives, and experience with their lives and property two systems of legitimization. Trapped minorities can be expected to struggle with the memory of the traumatic event or process that had the homeland taken over by a foreign power. 
The process of government create the city is included in the verses of AsySyu'ara 128-131.

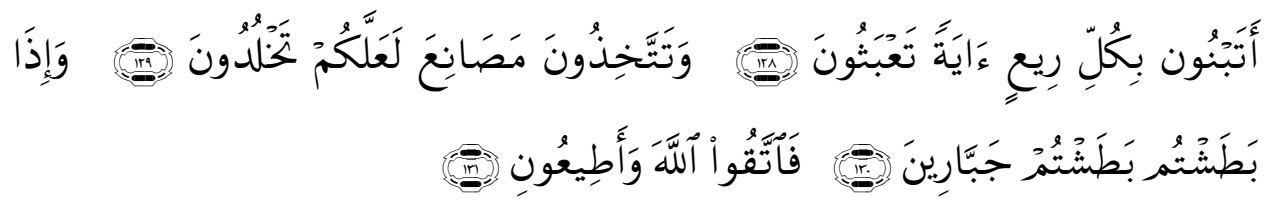

Translation:

"Do you build on every prominence, every high place, a monument, an edifice as a signpost for passers-by, so that you may hurl abuse? at those who pass by you and deride them. And you set up structures, for [extracting] water underground, that perhaps you might, as though you will, last forever, therein and not die. And when you assault, to smite or slay, you assault like tyrants, mercilessly!. So fear God, in this, and obey me, in what I have commanded you. (Al-Jalalayn in Hamza, 2007:421)

The verses describe about the people have built other buildings also for dwelling purposes, in order to make them grand, beautiful and strong, the people expend their wealth and mental and physical abilities in a manner as if people are going to live forever, and there is no aim of life except seeking of comforting and pleasure and nothing beyond this worldly life which might deserve their attention.

Based on the phenomenon of ambiguous Utopia City, the researcher will choose trilogy Hunger Games Movie as a media of the literary studies to analyze Panem as ambiguous Utopia and also the political power by Capitol in Panem. In Panem, there are some forms of city that created by Capitol. Capitol uses the power in Panem. Therefore, Panem seen peculiarity because the beautiful city which wanted by citizens never show in Panem.

The researcher is interested in analyzing Trilogy Hunger Games Movie because the movies are famous movie in the world which describes the condition of city which becomes ambiguous Utopia City and also describes the process of government creates the city. Then, the citizens do not fell enjoy and happy stay in their city because Utopia city is only a dream. There are many conflicts take place every time in Panem as ambiguous Utopia City. Based on the case of study background, the Researcher will focus on analyzing the processes of Capitol create Panem and also the forms of ambiguous Utopia city in Panem.

\section{LITERATURE REVIEW}

\section{A. Previous Studies}

Related with the study, there were some researchers who have analyzed the city in novels or movies. Nag (2013) used Post Colonialism approach in his thesis. His thesis entitled The Dystopia Vision: A Study of the Spatial Politics in E.M Forster's A passage to India). His thesis focused on the novel A Passage to India by E.M Forster. The novel combines several post-colonialist issues theorized by Bhabha and Said as well as postmodern ones philosophized by 
Foucault, Lefebvre and Soja. Postmodernism and Post colonialism go hand in hand often overlapping each other in matters of spatialization.

Then, Dwiwardani (2014) used post colonialism approach in her journal. Her journal entitled "Ruang Pascakolonial Dalam Kitchin Karya Yoshimoto. This study was conducted analyzing the relationship of significant textual units in the text, as well as linking it with the data outside using Sara Upstone's theory. In this research, there are representation of a colonial concept and traditional concept. Therefore, the representation of two groups, there are also depictions of chaos. It is a form of ideas that refuse combination that build opposition between colonial structures and traditional.

Related with the thesis of Nag and Dwiwardani, An Adzhanin (2014) also used post colonialism approach. Her journal entitled "Konstruksi Ruang Kota Postkolonial dan Respons Spasial dalam Novel The Kite Runner Karya Khaled Hosseini. She also used Sara Upstone's method of reading on spatial politics in postcolonial novels is used here to read how Fremont is constructed in the novel and the spatial respond occurred. The analysis showed that Khaled Hosseini's constructs Fremont that utopia is denied from the beginning of the novel. Fremont becomes oppressive space and yet, it offers possibilities for spatial responds such as displacement and carnivalisation to occur.

Based on the review of several previous studies using post colonialism approach, there are some similarities and differences. The similarities are all of the researchers use post colonialism approach in their researches and also all of them use concept of space by Upstone's theory which analyzes the concept of space and the conditions in the cities. All of the researchers also focus on analyze the city in their novels or movies. Then, the differences are all of the researchers do not analyze the forms of city and also they do not describe the process of colonizers create the city using concept of space, called post space.

\section{B. Conceptual Framework}

\section{a. Colonialism}

Reinhard in Stuchtey (2011:4) says that colonialism in terms of a history of ideas constitutes developmental differentia due to the control of one people by an alien one. Colonialism as the result of a will to expand and rule can initially be understood as a state that establishes an alien, colonial rule. Colonialism can be defined as the conquest and control of other people's land and goods. But Colonialism in this sense is not merely the expansion of various European powers into Asia, Africa, or the Americas form sixteenth century onwards. It has been a recurrent and widespread feature of human history (Lombaa 1998:2). 
Upstone (2009:4) says that Colonizers claim the area using the concept of space. The colonial achievement was often judged in terms of the subsequent productivity and political stability of the space. Systems of colonial rule can be broken into the binary classifications of direct and indirect rule. In systems of direct rule, Europeans colonial officials oversaw all aspects of governance, while natives were placed in an entirely subordinate role. Unlike indirect rule, the colonial government did not convey orders through local elites, but rather oversaw administration directly. European laws and customs were imported to supplant traditional power structures direct rule deliberately removed traditional power structures in order to implement uniformity across a region. Besides, indirect rule means the colonial power directed all decisions related to foreign policy and defense, while the indigenous population controlled most aspects of internal administration. This led to autonomous indigenous communities that were under the rule of local tribal chiefs or kings. These chiefs were either drawn from the existing social hierarchy or were newly minted by the colonial authority. Therefore, colonialism is a practice of the power which implicates violence or subjugation of one people to another.

\section{b. Post colonialism}

Post colonialism is one of the theories in Literature. This theory occurs after colonialism era. Post Colonialism focus on the trace of the colonialism in the countries that are subjugated. Bhabha in Ghaffarpour (2013:2) says that post colonialism has concept called hybridity. This concept describes about the vision of postcolonial theory that all cultures are confluence in each other and it can not be separated. In this regard, the diasporic writing becomes important it redefined the postcolonial aftermath not only in literature but also in socio cultural, political, national, economical.

In postcolonial studies the writing centre changed from the middle aged Europe to world over. The marginalized countries like India, Pakistan, Sri Lank, and other Asian Countries, outside Asia, Nigeria, Canada, Australia, South Africa and many Islamic countries are foregrounded in postcolonial studies. Therefore, Post colonialism as one of the theories in literature speaks about the human consequences of external control and economic exploitation of the citizens and their lands.

Post colonialism gives relation between the colonizer and the colonized. It questions the validity of the assumptions that the culture of colonizers is better than the culture of citizens. Since there are many people in many countries in the world that had experienced colonialism, post colonialism provides a crucial way in expressing the realities of the colonized people. Post colonialism is always engaged to its tendencies for the resistance toward the colonial notions in the mindset of indigenous or inlander (Upstone, 2009:5). The arena of contradictory condition usually involves in an alternative space that pinpoints to freedom, independency with no boundary and of independency itself. This alternative space post space has the prime aim, it is as am 


\section{alternative (space) that considers the postcolonial space in the national context. Upstone $(2009,85-113)$ says that there are some of the cities which describe about the concept of post colonialism such as Utopia city, Desire city, Nowhere city, and Carnival city.}

Postcolonial fiction should be seen as the arena of negotiation that put stake of politics power within it with nationalist power that represents post colonized nations. This is caused by two factors that cover it, the first is the engagement of colonial in the development of developing countries in the world and also it means for those countries as the symbol of anti-colonialism. Second is the resistance toward post colonialism in the scale of other space that focuses on the national politics blurred. For the result, it often causes the size to the local subversion just for the national (Upstone, 2009:28).

Based post colonialism theory, it can be concluded that post colonialism is an academic which analyzes, explains, shows and responds to the cultural legacy of colonialism and also imperialism. This theory describes about the human consequences of external control and economic exploitation of native people and their lands.

\section{c. Post Space}

Upstone (2009:1) says that in terms of space, such definition has meant that it is often the nation that imaginary space of government authority that seems to be the subject of political action. The centre of post-space is moving towards alternatives to considering the postcolonial space in national terms. Without spaces, any negotiation of place is incomplete. Upstone (2009:15) says that post space is where a chaotic sense of the spatial on all scales becomes a resource towards the re-visioning of the postcolonial position in society and consequent issues of identity. In this case, space does not only describe about the room or city but also describe about controlling the mind of residents. Therefore, the colonizers claim the area using concept of space.

Post emphasizes how such a space moves beyond colonial use of space to suggest order and border, and beyond those earlier definitions of space. In Post space, the residents who disagree with the space is created by colonizers, make a post space to against the space. Therefore, their city get chaos every time because there is different view between colonizers and residents

Upstone (2009:15) says that chaos is invoked by the postcolonial citizen gathered from the very sources of oppression and used against the colonial power in order to disrupt totalizations. While such chaos might seem only to open up new colonizations as it undermines the bordered territory or even the home as a defensive unit, it in fact provides powerful resistance. The authority that is gained by having absolute control of space is no longer recognized. 
Mahmud (2010:24) says that a boundary denotes a line while a frontier is a zone. In effect, a boundary girds a frontier. Frontiers zones at the periphery of political orders have over the last few centuries been replaced by defined lines of political control, the borders of the state. Besides, Mahmud (2010:26) says that in order to preserve their converging interests and to ensure a stable order whereby their conflicting interests can be mediated, different dominant classes structurally form a joint front to articulate their interests in the states apparatuses. Therefore, post space is a reason for the colonizers destroying the city because the residents disagree with the space of colonizers.

\section{d. Ambiguous Utopia City as Post Colonial Cities}

Upstone $(2009,85)$ says that the Ambiguous Utopia City is Postcolonial Cities. The colonialism's traces create the Utopia City become Ambiguous Utopia City. Postcolonial cities refer to those in what were previously colonial societies. However, postcolonial may also imply a particular critique, one which not only emphasizes the distinctive impact which colonialism has had on the economy, society, culture, spatial form, and architecture of the city but also on the way the city itself is understood and represented. So far, it has been assumed that postcolonial cities are focus on those cities existing in formerly colonized societies. Ambiguous city can be happed because there are some forms of city. Upstone (2009, 85-113) says that there are some forms of city such as Utopian City, Desire City, Nowhere City, Carnival City.

Sicoe (2013) says that Utopian depicts a future in that humanity has reached a state of balance and peace, and where all life is valued and maintained. There is no more suffering and injustice, no more ignorance and violence. In other words, has different point of view about utopia. The cities are inherently tied to utopian discourses to urban space not as lived, material reality, but as Dream (Upstone 2009:87). Therefore, Utopia city is impossible to be happened in this world because war, racism, and also bullying always happen every time. The city is inherently tied to utopian discourses to urban space not as lived, material reality, but as dream. Despite various representations of the horrors of the industrialized city, the city has also the same time a space of projection of personal desires and communal hopes. As the colonist justifies imperial seizure of area in ideal terms of adventure and freedom so utopia city is often the focus for similar yearnings. In both cases these ideals are in stark contrast to lived reality. As colonial space overwrites the freedom necessary for territorial expansion with ordering and division, so the utopian city succumbs to similar processes.

Morrison in Upstone (2009:89) has suggested that it is preciselyin the service of the magical that specifics of place must exist:

"if I'm going to - as I frequently do - impose either the divine, or the dream, or the supernatural into the narrative, then the places have to be very realistic. You have to anchor them ... . So, I try to have streets and towns and neighbor hoods, geography exactly the way it is or would be." 
Such statement of Morrison reveals much about Morrison's utopian cities, and the fact that they appear as both abstract and concrete. In these terms, specifics are also integral to the utopian dream without them the fantasy would lose a coterminous reality, a reality integral to the utopian city as it should suggest possibility, rather than escape. Therefore, Utopia city is a beautiful city only for the colonialism's view. This city is only a dream for the citizens because they do not see peacefulness in their city at all.

Upstone (2009:87) says that the connection between colonial cities and the utopian ideal city presents opportunities to show how postcolonial novelists engage with an urban space of idealized desire to investigate whether the relationship between colonial nation and post colony is replicated on the urban scale. The planner's desires are always subject to corruption or inherently prejudicial application. Desire City is in fact representative not of a tangible possibility, but instead of the unrealizable dreams of the postcolonial citizen, whose past is corrupted permanently by the disruption of colonial rule (Upstone 2009:87). Desire towards a city means that citizen desires to move to a particular city and live their life in that city. The characteristics of desire include such as the conflict between morality and seduction, and the role of imagination. Desire shows as a powerful emotion that can be best described as passion. However, desire is felt by informants as a two sided phenomenon. Positive, energizing, and motivating, at times, desire becomes overpowering, addictive, and uncontrollable. Popova (2013:9) says that the consumers describe themselves as being seized, enslave, and captured by their desires. This is not an ability to control desire add to its seductive nature and mythical power.

Ondaatje in Upstone (2009:91) says that frames the interrogation of the Sri Lankan civil war with the desire to recover cities, an action of restoration that offers the possibility of a more hopeful urban landscape:

"Most of what Sarath wished to know was in some way linked to the earth. His desire, he had told her, was to write a book someday about a city in the south of the island that no longer existed. Not a wall of it remained, but he wanted to tell the story of that place. It would emerge out of this dark trade with the earth, his knowledge of the region in chronicles."

The reemergence of the cities of the past in such a way not only foregrounds an overwritten space, but also reasserts the unconventional temporality usefully captured in the concept of messianic time already identified as a feature of Rushdie's urban space. Therefore, desired city is a city when the citizens want to see their old city that they do not see again in present and even in the future. 
All of the representations are utopian promise undercut with strong consciousness of urban space's power inequalities combating ideals from being realized. The emphasizing many of the elements in utopian cities, postcolonial representations ultimately refuse the utopian label. Instead, elements of utopia cities illuminate the intensely subjective nature of urbanity. That one person's utopia is another's dystopia. Sometimes, colonialism people try to make the citizens believe to them in the city. Ironically, the negative vision is the only way the postcolonial novel presents utopia in the traditional sense. Upstone (2009:97) says the representations of cities it offers truly are nowheres that form the disclaimed under sides of the real.

The citizens are trapped in their city because they do not feel stay the real utopia city. This is not a rejection of the city, but rather suggests a radical revision, questioning the premise that it is possible to construct an ideal, objectified space capable of serving a disparate population. Thus on the urban scale, as with the journey, both colonial commanding and its contemporary legacy are undercut. In illuminating the limits of the utopian urban order its underlying chaos so each author also reveals the limits of what may be seen as a parallel colonial ordering. In its most obvious form, to a more general comment on the insidious control of public space, reinforced by media technology. Rather, in common with the depressing and dystopian visions of the city I have outlined, the urban space is the most problematic to successfully revision (Upstone, 2009:103).

Chamchain in Upstone (2009:94) says that the notion of sight so connected to the colonial control of territory is again emphasized:

"The city thickened around them as a forest; the buildings twined together ...

'No light can get in here,' she whispered to him. 'It's black; all black."

The city itself becomes an enemy, the riddle that must be solved. Therefore, Nowhere city is still policed and the confusion remains because the visions of colonialism are not showed so the citizens are trapped in their city.

In Carnival city typically incriminates a public celebration and/or parade combining some elements of a circus, masks, and a public street party. Carnival city was created to respect each other. The residents are flocked into the city only to find a prosperous life. All the citizens always fell happy and comfortable in the city although there are many differences such as culture and even religion. Carnival represented more than a licensed inversion of accepted norms. It embodied an ongoing struggle against inequity and oppression. Gilbert and Tompkins (1996:83) say that Carnival presupposes the possibility of social reform by activating the communal imagination.

Upstone (2009:104) says that there are central to such revizioning and need opinion, strategies which can be referred to as carnivalization and displacement. The possibilities of examining spaces are smaller than as well as larger than the nation space. It is to further development of this need that the strategy of displacement is invoked, where the city gradually shifts out of focus in deference to its microstructures. Upstone said (2009:104) in 
carnival city, the ethnic who minorities who come in new place have aim to produce does not mean taking over an entire city, but rather involves celebrating difference at the level of the public buildings and certain open spaces which construct the city. The new citizens always think that their new place is the best place than their old place because there are many cultures there. But, in fact, the happiness is only briefly. Chaos occurs every time because there are many differences point of view such as traditions or customs, and even religion. Some of the citizens think that their traditions should be develop in the city but some the citizens do not agree with the traditions so war, racism, and even bullying always occur every time.

Amadahy and Lawrence in Kempf (2009:118) say that the from Poem by Lillian Allen reflects the ambiguous position of Black people in Canada relative to Indigenous peoples, as portrayed in critical Black writing.

\author{
Unnatural Causes \\ Dry rivers in the valley \\ The thirst at the banks of plenty \\ The room at the streetcar shelter \\ A bus stop bed... \\ The last postcard you sent was kinda weird \\ Poor people sleeping at the bus stop? \\ Surely you don't have that there? \\ Anyways, I'm dying to come to Canada \\ I'm a pioneer. \\ (Lillian Allen 1989)
}

In her poetry, Allen includes the realities of those who leave homes already devastated by colonialism globally, those who have bought in to the myth of Canada as an empty land where they can remake themselves and their lives, and the violence of racism that all Black migrants encounter at the point of arrival in Canada. Therefore, Carnival city is a place for the citizens to stay together with differences culture, religion, traditions, and visions. Unfortunately, chaos traps all of the citizens because they do not care each others.

\title{
e. Synopsis of Trilogy Hunger Games
}

Since the release in 2008 of The Hunger Games, this movie has become increasingly because there is something of a cultural phenomenon that showed in The Hunger Games movies. The Hunger Games is written by Suzanne Collins who had previously achieved success as the author. Suzanne Collins made the trilogy novel of Hunger Games based on her experience. Her Father is an army. Her Father has a job to war in Vietnam. Therefore, she always gets information about the war from her Father. Her Father tells Collins about the war and the effect of war so Collins feels interesting to make novels that tell about war and the 
effects of war. Beside, Suzanne Collins also drew her inspiration for the trilogy of Hunger Games from imagining a cross between the war in Iraq and reality $\mathrm{TV}$, after flipping through the channels one night and seeing the juxtaposition between the coverage of the war and reality TV programming (Wilson, 2010: 271).

The popularity of the series also results from the immense success of the Hollywood film adaptation of The Hunger Games, which was released in 2012 by Lions Gate. The Hunger Games (2012) set records for the opening day and the biggest opening weekend for a non sequel film. Catching Fire (2013) set the record for biggest opening weekend in the month of November. Mockingjay Part 1 (2014) had the largest opening day and weekend of 2014. The movies, including The Hunger Games Mockingjay Part 2 (2015), received a positive reception from critics, with praise aimed at its themes and messages. The film has grossed approximately $\$ 408$ million in ticket sales, for a rank of thirteenth all time box office sales in the U.S (Peters, 2013:1).

The first movie in trilogy Hunger Games is The Hunger Games. The movie serves as introduction to the Capitol's oppressive power and to the main characters. The story takes place in the future in Panem, a new country built on the ruins of North America, which is organized into twelve outlying districts that serve a geographically protected Capitol. The narration starts on the day of the reaping, a lottery to select from each of the twelve districts one boy and one girl between the ages of twelve and eighteen. The tributes must represent their home district in a televised fight to the death known as the Hunger Games. The Hunger Games are used as a punishment for the rebellion seventy four years earlier, in which one of the districts. The thirteen was obliterated for daring to challenge the Capitol's power.

The second movie in Trilogy Hunger Games is Catching Fire. Catching Fire demonstrates the growing tensions between all of the districts and the Capitol and sends Katniss back into the arena again. The narration follows Katniss as she attempts to quiet the discontent in the districts during the Hunger Games Victory Tour, but She only intensifies the unrest. Katniss and Peeta get engaged as a way to prove their undying love for each other, but they do not carefully instigate stricter government control in District 12. When the Quarter Quell as Seventy Fifth Hunger Games is announced, Peeta and Katniss find themselves preparing to enter the arena for a second time against other past Hunger Games victors.

The third movie is Mongkingjay Part 1 and Mockingjay Part 2. In Mongkingjay part 1, the rebellion was being led, and reluctantly agreed to become its poster girl as long as her fellow tribute Peeta was rescued. She was broadcast giving an angry speech after seeing her home District in ruins, and rebels in District 7 were killed as a result. The Hanging Tree became the song of the rebellion after Katniss was broadcast singing it. During a propaganda interview, a 
beleaguered looking Peeta warned that District 13 would be attacked. His warning gave the rebel time to hide underground, and no lives were lost. Peeta was rescued but after months of torture and mental conditioning, he was no longer himself, violently attacking Katniss upon sight and attempting to strangle her. In Mockingjay part 2 is the conclusion of the global phenomenon Hunger Games film series, Katniss Everdeen stakes her claim as the leader of District 13, and orders the revolution against President Snow and the Capitol in Panem. Meanwhile, her brainwashed former love interest Peeta joins the rebellion's perilous mission to assassinate President Snow.

Therefore, Trilogy Hunger Games is one of the best stories which created by the best author dystopian, Suzanne Collins. The stories are interesting so the lions Gate as American Film Production Company made Trilogy Hunger Games become the Movies. These movies tell about the condition of Panem as city that destroyed by the Capitol so the citizens do not enjoy and comfortable stay there.

\section{RESEARCH METHODOLOGY}

In this research, the Researcher used descriptive qualitative method based on the characteristic of the research. Descriptive qualitative method seeks with qualitative phenomenon especially in behavioral sciences where the purpose is to detect the underlying motives of human behavior (Kothari, 2004:17). Descriptive qualitative method could be identified as important and appropriate for research questions focused on discovered the events or experienced and on acquired insights from informants regarded a poorly understood phenomenon.

It dealt with the condition of relationship that existed in Trilogy Hunger Games Movies. This research described about the phenomena of ambiguous Utopia city that happened in Panem and also the processes of colonizers created ambiguous Utopia City.

The data source took from Trilogy Hunger Games Movies as the primary data and related book and some references which were connected with the ambiguous Utopia City and process of Capitol created the city as the secondary data in completing this research.

In this research, the researcher analyzed Trilogy Hunger Games Movie to collect the data which related with this research. The steps to collect the data were as follows:

a) The researcher watched Trilogy Hunger Games several times thoroughly

b) The researcher found out the processes of capitol created the city and the forms of city in Panem as Ambiguous Utopia City.

c) The Researcher wrote the processes of capitol created the city and the forms of city in Panem as Ambiguous Utopia City

d) The researcher selected the data which were relation with the purpose of the study 
After collected the data, the researcher analyzed the data through these steps as follow. First, displayed all of the data found in Trilogy Hunger Games. Second, the researcher categorized the processes of Capitol create the city and the forms of ambiguous Utopia City in Panem. Third, the researcher wrote down the processes of Capitol create the city and the forms of ambiguous Utopia City in Panem. Fourth, the researcher analyzed the processes of Capitol created the city and the forms of ambiguous Utopia City in Panem. Finally, the researcher redrew the conclusion of the processes of Capitol create the city and the forms of city in Panem as ambiguous Utopia City.

\section{FINDINGS}

In this chapter, Researcher presents findings and discussion of Trilogy Hunger Games Movies that consist of Process of Capitol Create Panem as Ambiguous Utopia City and the several forms of Ambiguous Utopia City in Panem using concept of space by Upstone.

\section{The processes of Captiol's Creation in Panem as Ambiguous Utopia City}

The ways of Capitol were identified and analyzed based on the concept of space by Upstone's theory, called post space. In Trilogy Hunger Games Movies, Capitol creates post space using the border and also the order to the residents in every District. Therefore, the city becomes ambiguous Utopia City because the chaos from the post space occurs in the city.

\section{a) Capitol borders the situation in Panem}

Capitol creates a border between Capitol City and all of the Districts in Panem to solve the rebellion. The result of bordering is injustice occurs in Panem. There is a space between Capitol people and the residents who stay in every district. People in Capitol live with much money and good facilities. Besides, the residents in all Districts stay in dirty and ugly places.

\section{Datum 1: The Space}

Description: In Datum 1, Capitol creates the space between the residents in every District and the Capitol. Capitol limits the activity of residents who wants to hunt or walk out of their district. The residents are forbidden to do something in the other lands so the Capitol creates the wall to make a space between the residents and Capitol's Land. The way to create a wall between Capitol and residents can be indicated that Capitol makes a border between Capitol and the residents in every District. (03:32, on Hunger Games)

\section{Datum 2 : Rich City and Poor City}

Description: All of the people in Capitol are happy and comfortable because they always get what they want every time. There are many foods and drinks, and also party every time if they want. They always use elegant style if they want to walk around the Capitol. They are never afraid and 
frightening because the peacekeepers of Capitol always protect them in Capitol. Besides, in picture 4.3, All of the residents are uncomfortable stay in their city because there are no foods, drinks, or good facilities. (Picture 4.2 26:42, on Hunger Games and picture 4.3 14:03, on Catching Fire)

\section{Datum 3: Suppressed Communication}

Description: This scene above, Katniss talks to the members of district 13 who want to make rebellion in Panem. President Coin as the leader of district 13 suggests Katniss to persuade all districts to join together against the Capitol. Katniss has to make propaganda on television so all the districts can get the meaning of Katniss. But, Capitol has many ways to solve the problem. One of the ways is turn out the network in Panem so the residents do not show their purpose and they can not influence each other. Luckily, Beetee as the protagonist character in Trilogy Hunger Games Movies successes to relate again the network which is vanishing. (6:04-6:24 on Mockingjay Part 1)

\section{b) Capitol orders the residents in each District}

Capitol controls the residents who want to make rebellion in Panem using the dangerous order.

\section{Datum 4: Lottery of Death}

Captiol's Announcer: But Freedom has a cost. And the traitors were defeated. We swore as nation we would never know this treason again. And so it was decreed that each year the various districts of Panem would offer up, in tribute, one young man and woman to fight to the death in a pageant of honor, courage, and sacrifice.

Description: In this scene, the researcher found the post space that created by Capitol to destroy every district. Capitol creates a deadly game to make the residents feel afraid with Capitol. The Game is called Hunger Games. The place of this game is in the forest which arranged by Capitol with the dangerous system. In Hunger Games, Capitol orders the residents in every district for delegating one man and one girl. The rule of this game is killing each other to live and the winner in this game will get much money after the game. The purpose of Capitol to create the game is reminding the residents that Capitol is stronger than them and they can not make rebellion again like want they did in the past. Based on the citation of Capitol's announcer, the researcher can be concluded that there is an order of Capitol to the policy the residents in every District. (Picture 4.5, 13:20-13:42 and Picture 4.6, 14:46 on Hunger Games) 
Datum 5: Reaping Day

President Snow: The $75^{\text {th }}$ anniversary of our defeat rebellion, we celebrate the $3^{\text {rd }}$ Quarter Quell as a reminder that even the strongest cannot overcome the power of Capitol. On this, the $3^{\text {rd }}$ Quarter Quell games, the male and the female tributes are to be reaped from the existing pool of victors in each district. Victors shall present themselves on reaping day regardless of age state of health or situation.

Description: In this scene, Presidents Snow as the leader of Capitol in Panem gives a bad news for all of the residents in every district. President Snow tells that the capitol will organize the special game for celebrating the anniversary of Capitol that success to solve the rebellion. Therefore, President Snow wants to make another deadly game called Quarter Quell. In this game has a similarity with the Hunger Games but the members or tributes are from all of the winners in Hunger Games. The winners of Hunger Games have to kill each other again in Quarter Quell. Presidents Snow makes the games because $\mathrm{He}$ is disappointed with Katniss and Petaa as the main characters that destroyed the rule in Hunger Games. Therefore, President Snows commands all of the winners in every district to fight again so the rebellions symbol that created by Katniss and Petaa is gone. Based on the case, the researcher can conclude that President Snow as the leader of Capitol uses He's power to order the residents in Panem. (46:02-46:50 on Catching Fire)

\section{DISCUSSION}

In this Part, the researcher explains the data analysis which had been found from the findings above about the processes of Capitol create Panem as Ambiguous City and also the forms of Ambiguous Utopia City in Panem. The Researcher analyzed using Upsone's Theory which describes Post Space. Post emphasizes how such a space moves beyond the colonial use of space to suggest order and border, and beyond those earlier definitions of space. In the space, the colonizers have purposes to border and to order the residents in the city so the city of residents sustain chaos or post space every time. Mahmud (2010:24) says that a boundary denotes a line while a frontier is a zone. In effect, a boundary girds a frontier. Frontiers zones at the periphery of political orders have over the last few centuries been replaced by defined lines of political control, the borders of the state. 
The idea of the frontier had a particular purchase in the colonial imagination. Therefore, Border is the human constructs built through prevailing constellations of power. Besides, Mahmud (2010:26) says that in order to preserve their converging interests and to ensure a stable order whereby their conflicting interests can be mediated, different dominant classes structurally form a "joint front" to articulate their interests in the states apparatuses.

Therefore, the ways to analyze the processes of Capitol create Panem focus on the border and order that created by Capitol. On Trilogy Hunger Games, Capitol City is the central city in Panem that control the Human life in Panem. President Snow as the leader of Capitol always limits the activities of the Residents in each District. He uses the crazy rules which make all the residents are uncomfortable and afraid stay in Panem even in their city. Therefore, there are two ways of Capitol create Panem as Ambiguous Utopia City such as Border and Order.

Capitol creates the border to control Panem. Upstone (30:2009) says that colonial states manipulated borders at independence to maintain existing boundaries or claim the right to define new ones. On Trilogy Hunger Games, Capitol claims the area of Panem with maintain existing boundaries. Capitol creates a space between the residents who stay in Capitol and the residents who stay in each District to show their power so the residents in every district do not make rebellion again.

In Datum 1 picture 4.1, Capitol limits the activities of Capitol. All of the residents can not go to another place because Capitol creates the wall that written "DISTRICT BOUNDARY NO ACCESS BEYOND THIS POINT". The residents must stay in their city. They can not go to another place without the instruction of Capitol because the peacekeepers of Capitol always keep watch around the wall so they will get punished if they cross the border.

Then in datum 2 picture 4.2, Capitol invites Katniss and Petaa to come in Capitol City. They are invited by Capitol because they have to join in deadly games, called Hunger Games. Capitol gives them good service such as modern transportation, many foods, many drinks and awesome building. This situation is different in their district. They never get good facilities in their district. Katniss and Petaa live in the poor situation. In datum 2 picture 4.3, the situation of district 12 looks sadly. All the Residents have to stay in ugly place. There are no foods, drinks, and even good facilities. Almost the residents are hungry ever time. They do not much money to buy something even a piece of bread. Based on the pictures and cases above between picture 4.2 and picture 4.3 in datum 2 , the researcher has found out space between Capitol City and each District. President 
Snow as the leader of Capitol makes injustice situation in Panem. All of the people in Capitol can get what they want but in other hand, the residents in every District fell hungry every time.

In datum 3 picture 4.4, Capitol disconnects the network of the residents in each District. In another hand, all of the people in Capitol City can use network whenever they want. Capitol breaks the network because Katniss as the Mockingjay wants to persuade all of the residents who stay in every district to fight together against Capitol. Therefore, Capitol wants to solve the rebellion with breaks all of the accesses network in ever district so they can help each other. Based on the case, the Researcher has found the border between Capitol City and every District in Panem. The good facilities in Capitol do not occur in every district in Panem.

Then, Capitol also uses the order to create Panem as Ambiguous Utopia City. Upstone (2009:8) states that in spatial terms, what colonial ordering obscures is a more chaotic reality. The colonizer's system ultimate desire is for the same ordering and territorial control trade agreements, outlaw of competition, economic enclaves which exemplified the colonial project. Order as continually revealing chaos, that the colonizer discovered a chaotic world which it then tamed with order imported from the imperial homeland.

On Trilogy Hunger Games, Capitol as the central city in Panem wants to control the situation in Panem. Capitol is ordering the residents in every district. Capitol commands the peacekeepers as the soldiers of Capitol to watch over all Resident's activities in every district. Capitol is afraid if the residents do not agree with the Capitol's system so Peacekeepers have to observe their activities to solve the rebellion of the Residents.

In datum 4 picture 4.5 , the Residents of District 12 are afraid with the situation. They are frightening because the Capitol want to announce who are the residents join with them to the Capitol. In datum 4 Picture 4.6, the agency of Capitol announces the participants who will join in the games. She is ordering the residents to join in Hunger Games. The Game commands the residents to kill each other. The members are taken from each district in Panem. Capitol uses this game to remind again the power of Capitol who success to solve the rebellion of the residents who disagree with the Capitol's system in Panem.

In datum 5 picture 4.7, President Snow as the leader of Capitol announces again the deadly game, called Quarter Quell. In this game, all of the residents who are the winner in Hunger Games have to kill each other again. President Snow organizes the games to celebrate the anniversary of Panem and also the big reason of Capitol to solve the rebellion of Residents. This announcement makes all of the winners are anxious and uncomfortable. In datum 5 picture 4.8 Katniss and Peeta are watching the announcement of President Snow on TV. They are very 
disappointed to Capitol. Capitol promises that the winners of Hunger Games will get comfortable situation after the Game but in fact, Presidents Snow wants to kill them. Presidents Snow is ordering the games because Katniss and Peteaa disagree with the system of Capitol in Hunger Game. Therefore, based on the cases above in each scene, the researcher found the processes border and order of Capitol destroy the situation in Panem so Panem becomes Ambiguous Utopia City.

\section{CONCLUSION AND SUGGESTION}

\section{A. Conclusion}

The researcher found the processes of Capitol create Panem as Ambiguous Utopia City in Trilogy Hunger Games Movies. First, Capitol borders the place between Capitol and every District in Panem. The Capitol creates an injustice condition in Panem so the residents feel confuse stay in their city. All the residents who stay in Capitol get the good facilities. In Another hand, all of the residents who stay in each district get bad facilities. Second, Capitol orders the residents. Capitol creates the rule that makes the residents uncomfortable stay in Panem. Capitol commands the residents to kill each other in Hunger Games and Quartel Quell so the residents who disagree with the system make the rebellion in Capitol.

\section{B. Suggestion}

Based on the conclusion above, the Researcher gives suggestion as the following below:

1. The researcher suggests to the readers to improve their knowledge in Literature. They have to learn deeply the approach of Literature Especially Post colonialism by Upstone's theory.

2. For the researchers who want to analyze the concept of space, they have to find out some information about Upstone's theory because Sara Upstone describes many concept of space in her book "Spatial Politic in Postcolonial Novel".

3. The residents have to respect each other without using border and order that have a purpose to destroy the city. Therefore, the colonizers can not change the city become Ambiguous Utopia City.

\section{REFERENCES}

An Adzhani, Sabrina. 2014. Konstruksi Ruang Kota Poskolonial dan Respons Spasial Dalam Novel The Kite Runner Karya Khaled Hosseini. Universitas Brawijaya. Jawa Timur.

Bartens, Hans. 2001. Literary Theory The Basics. London and New York: Routledge.

Bhabha, H. K. 1994. The Location of Culture. London \& New York: Routledge.

Claeys, Gregory. 2010. The Cambridge Companion to Utopian Literature. Cambridge University Press. Cambridge 
Collins, Suzanne. 2008. The Hunger Games. New York: Scholastic Press

Collins, Suzanne. 2013. The Biography Channel website. Available Website on: HYPERLINK "http://www.biography.com/people/suzanne-collins20903551" http://www.biography.com/people/suzanne-collins-20903551 .Accessed on March 20 ${ }^{\text {th }}, 2017$.

De Saussure, Ferdinand. 1959. Course in General Linguistics. New York: Philosophical Library.

Dwiwardani, Wury. 2014. Ruang Pascakolonial Dalam Kitchin Karya Yoshimoto Banana. Jurnal Poetika. Volume II No. 1. Page 55-68. Yogyakarta.

Drucker, H. (1974). The political uses of ideology. New York, NY: Harper \& Rox Publishers, Inc.

Friedman, C Michael. 2014.Notes on Note-Taking: Review of Research and Insights for Students and Instructors. Harvard University. Cambridge.

Ghaffarpur, Roya. 2013. A Postcolonial Appraisal of Suzanne Collins' The Hunger Games in the Light of Bhabha's Ideas. Islamic Azad University. Karaj Branch.

Hamza, Feras. 2007. Tafsir al-Jalalayn. Royal Aal al-Bayt Institute for Islamic Thought Amman. Jordan

Kempf, Arlo. 2009. Breaching The Colonial Contract Anti-Colonialism in The Us and Canada. University of Toronto. Ontario.

Khotari, C.R. 2004. Research Methodology: Methods and Techniques. New Delhi: New Age International (P) Limited, Publishers.

Kohn, Margaret. 2006. "Colonialism” Stanford Encyclopedia of Philosophy. Stanford University. Stanford.

Loomba, Ania. 1998. Colonialism/Postcolonialism. New York: Routledge.

Mahmud, Tayyab. 2010. Colonial Cartographies, Postcolonial Borders, and Enduring Failures of International Law: The Unending Wars Along the Afghanistan-Pakistan Frontier. Brooklyn Journal of International Law. Volume 36 No.1. Page 1-75. Brooklyn.

Nag, Souray Kumar. 2013. The Dystopia Vision: A Study of the Spatial Politics in E.M Forster's A passage to India. Epiphany Journal. Volume 6 No. 2. Page 93-99. New York.

Rabinowitz, Dan. 2001. The Palestinian Citizens of Israel, The Concept of Trapped Minority and The Discourse of Transnationalism in Anthropology. Ethnic and Racial Studies. Volume 24 No. 1. Page 64-85. Taylor \& Francis.

Ritchie, Jane and Jane Lewis. 2003. Qualitative Research Practice. London, California, and New Delhi: SAGE Publications.

Said, Edward. 1977. Orientalism. London: Penguin.

Sennet, Richard. 1969. Classic Essays On The Culture Of Cities. New Jersey: Englewood Cliffs

Sunder, Miriam. 2013. Satire and Ambiguity in Thomas More's Utopia. Goteborgs Universitiet. Engelska. 
Sicoe, Veronica. 2013. Utopia and Dystopia- The many faces of the future Available Website on: htpp://222.veronicasicoe.com/blg/2013/04/utopiaand-dystopia-the-many-faces-of-the-future. Accessed on March $24^{\text {th }}$, 2017.

Stovall, T Rene'e. 2015. To Kill A Mockingjay: An Ideological Criticism of The Hunger Games. West Texas A\&M University. Texas.

Stuchtey, Benedikt. 2011. Colonialism and Imperialism. Available Website on: HYPERLINK "http://ieg-ego.eu/en/threads/backgrounds/colonialism-andimperialism" http://ieg-ego.eu/en/threads/backgrounds/colonialism-andimperialism . Accessed on March 24 ${ }^{\text {th }}, 2017$.

Upstone, Sara. 2009. Spatial Politics in the Postcolonial Novel. Farnham \& Burlington: Ashgate Publishing Limited.

Wilson, Leah. 2010. The Girl Who Was on Fire: Your Favorite Authors SuzanneCollins' Hunger Games Trilogy. Texas: BenBella Books. 